\title{
Insights From Research on Distance Education Learners, Learning, and Learner Support
}

Richard E. West

rw@byu.edu

Follow this and additional works at: https://scholarsarchive.byu.edu/facpub

Part of the Educational Psychology Commons

\section{Original Publication Citation}

R. E. West, (29). Insights from research on distance education learners, learning, and learner support. Distances et savoirs. 7(4). doi: 1.3166/DS.7.571-584.

\section{BYU ScholarsArchive Citation}

West, Richard E., "Insights From Research on Distance Education Learners, Learning, and Learner Support" (2009). Faculty Publications. 861.

https://scholarsarchive.byu.edu/facpub/861

This Peer-Reviewed Article is brought to you for free and open access by BYU ScholarsArchive. It has been accepted for inclusion in Faculty Publications by an authorized administrator of BYU ScholarsArchive. For more information, please contact ellen_amatangelo@byu.edu. 


\section{A Summary of Section II, Insights From Research on Distance Education Learners, Learning, and Learner Support Michael G. Moore (2007) Handbook of Distance Education}

\section{Richard E. West}

Instructional Psychology and Technology Department

Brigham Young University

rickwest@byu.edu

RÉSUMÉ. (French translation of abstract below. We will provide it)

ABSTRACT. This article reviews the key ideas related to increasing student learning and support described in selected chapters from the second edition of the Handbook of Distance Education (Moore 2007). These chapters described research findings related to the impact of distance education on learners in general (student autonomy, cognition, social learning, and satisfaction), as well as specific subgroups of distance students and instructors (K-12, female, and disabled students as well as academic advising and library services). This article concludes with brief recommendations for future research in each of these areas.

MOTS-CLÉS : un maximum de mots significatifs, en français et en anglais, doivent être isolés sous forme de mots-clés.

KEYWORDS: a maximum of significant words, in French and in English, will be separated as key words.

D\&S. Volume $X-n^{\circ} \mathrm{x} / 2009$, pages 1 à $\mathrm{X}$ 
Distance learning (DL) has finally reached the tipping point. No longer the ignored sibling of face-to-face (F2F) learning, distance education has enough participation to merit full attention in educational, political, and popular discussions. It is appropriate, then, to consider what educational researchers have learned about distance education, including its effects on learners and the learning process. Also, the pool of distance education participants is wide enough to begin scrutinizing our efforts with supporting specific subgroup populations. In this article, I discuss the research presented in the Handbook of Distance Education (Moore 2007) related to distance learning (from a cognitive and social learning perspective), learners, and learner support.

\section{Distance education learners}

\section{Independent Learning}

A hallmark of distance education has been its reliance on learner autonomy, also called independent or self-directed learning. Anderson (2007) reviewed the research on autonomous learning and described two useful frameworks (Garrison 1997; Peters 1998) for understanding the complex nature of independent learning. These frameworks posit two dimensions of autonomous distance learning: self-management of pedagogy and self-monitoring of cognition, or metacognition (Garrison added motivation, which Anderson interprets as a mediating force on the other two). When students effectively self-manage, they recognize and control their learning goals and their outward learning strategies and efforts. When self-monitoring their cognition, they recognize and control their inner cognitive strategies.

In his review, Anderson cited Moore's (1980) theory of self-management, or learner autonomy as Moore called it, which posited that more autonomous learners would prefer courses with less transactional distance. Chen and Willits (1999) later used factor analysis to extend this research with students engaged in a videoconferencing environment. They found that autonomy was actually a combination of the cognitive style variables independence and interdependence (learning individually and collaboratively). Anderson (2007) pointed out that that this means individuals' autonomy as distance learners must be understood as including their abilities to work with others.

In reviewing research related to student metacognition, Anderson (2007) reported White's $(1995 ; 1997)$ findings that distance learners used metacognitive strategies of self-monitoring and self-evaluation mmore than F2F students did. White (1999) later found that knowledge about one's self and strategies was more important for successful learning than knowledge about the tasks and goals, indicating that self-monitoring could be more helpful even than prior knowledge of 
a subject. However, Anderson also reviewed Jegede, Taplin, Fan, Chan, and Yum's (1999) finding that DL students did not meaningfully use metacognition to monitor, organize, and reflect on their learning, although high achievers did so more than low-achieving students. Anderson explained that these differences might be due to cultural, interactional, and technological variances, indicating a need for more clarifying research.

In addition to studying whether autonomy impacts learning, researchers have wondered whether participating in DL can develop autonomy in learners. Anderson (2007) cited a study by Ching (1998) who used cross-sectional and longitudinal data to report that field-dependant learners became more field independent (in other words, they developed the cognitive style of being more autonomous in their learning) as they participated in DL, although Anderson (2007) felt the conclusions are still premature pending further research.

\section{Impact of Distance Education on Student Satisfaction}

Allen, Burrell, Timmerman, Bourhis, and Mabry (2007) reviewed statistical meta-analyses related to student satisfaction with distance learning in an attempt to discover how students, in general, feel about their DL experiences. They reported that authors of two major meta-analyses of 25 studies (Allen, Bourhis, Burrell, Mabry, Emmers-Sommer, and Titsworth, et al. 2002) and 154 studies (Bernard, Abrami, Lou, Borokhovski, Wade, Wozney, et al. 2004) found that students typically are slightly more satisfied with face-to-face environments over distance learning ones.

However, Allen et al. (2007) wisely caution against the limitations of the findings. For example, the difference between how students felt about their DL and F2F courses shrunk, grew, and in some cases the effect was reversed with students preferring DL over F2F. These changes were due to factors such as the media used in the courses (small preference for video over audio and text in DL), the quality of specific DL and F2F options, student learning styles, the synchronicity of the DL communication (some evidence that distance students preferred asynchronous), and the amount of interaction within a course (some evidence that distance students preferred less interaction). Another weakness of the research is that many of the studies studied DL that utilized older technologies, before communication methods could be integrated into one technology. In addition, Allen et al.'s analysis only looked at fully online or fully face-to-face environments, ignoring the very common blended model that integrates elements of both. The authors concluded that there is not enough evidence to claim general F2F/DL differences in student satisfaction, but there is evidence to promote matching effectively designed learning environments with particular student needs. 


\section{Distance education learning}

\section{Cognitive Perspectives on Distance Learning}

Information processing is a common theoretical framework for designing distance learning. Hannafin, Hill, Song, \& West (2007) reviewed the literature exploring how three information processing principles (motivation, cognitive demands, and metacognition) can be applied to technology-enhanced distance learning environments. They reported evidence from Bures, Amundsen, and Abrami (2002) that intrinsic and extrinsic motivational factors in a computer conferencing course can impact satisfaction. Additionally, students' own intrinsic motivation was related to their participation and performance in the course. Another research study was cited as also showing that this student motivation can be influenced by how well the students manage the social and technical aspects of a course (Whipp and Chiarelli 2004).

Hannafin et al. (2007) also found that, contrary to some beliefs, online learning is not inherently motivating and can even be demotivating due to technological (lack of familiarity with the technology), intrapersonal (personal relevance of the learning tasks and beliefs about computers' impact on learning), and interpersonal (managing distance collaboration) hurdles (Bures, Amundsen, and Abrami 2002; Schrum, Burbank, Engle, Chambers, and Glassett 2005; Schmeekle 2003). However, online learning can be made more motivating through the effective use of multimedia, including context-based videos (Hee Jun and Johnson 2005) and perhaps an exploratory course design (Hsinyi, Chin-Chung, and Ying-Tien 2006).

There are different kinds of mental demands that learning can place on a students' cognitive processing. One type of cognitive load (germane) is helpful for learning efficiency by creating mental schemas for processing future information, while extrinsic and intrinsic cognitive load can make learning more difficult. Hannafin et al. (2007) found that research suggests hyperlinking can increase extrinsic cognitive load (Eveland and Dunwoody 2001; Niederhauser, Reynolds, Salmen, and Skolmoski 2000), as can concurrently learning the distance technologies along with the subject material (Clarke, Ayres, and Sweller 2005).

However, instructors can increase germane (or useful) cognitive load in online settings by using traditional scaffolding techniques. For example, Hannafin et al. (2007) cited studies where researchers provided students with worked-out, step-bystep examples of problems they are to solve, encouraged students to use selfexplanation, or used example elaboration/comparison or fading methods. In one study, researchers found that increasing germane cognitive load through a nonlinear website hampered recall of factual information but improved how well students understood relationships between the concepts. This may indicate that nonlinearity could be beneficial for improving germane cognitive load (Eveland, Cortese, Park, 
and Dunwoody 2004), but must be balanced with the negative impact it can have by also increasing extrinsic cognitive load.

Metacognition is critical for online learners because of the need for autonomy, as discussed by Anderson (2007). Hannafin et al. (2007) reported that providing even small metacognitive prompts and supports significantly helped online learners (Bannert 2003; Kaufmann 2004; Zion, Michalsky, and Mevarech 2005), and having metacognitive skills was related to online success (Smidt and Hegelheimer 2004) and helped compensate for poor system or domain knowledge (Land and Greene 2000). Schwartz, Anderson, Hong, Howard, and McGee (2004) found that metacognitive skills were especially critical for students in nonlinear online environments. Thus, the authors recommended especially designing these environments to include familiar conventions for students to utilize. These findings provide great insights into how to effectively design online learning based on established cognitive principles.

\section{Group development in Online Distance Learning Groups}

Much discussion about distance learning revolves around online groups and computer-based collaboration. Carabajal, LaPointe, and Gunawardena (2007) found that historically researchers have identified three main kinds of group development models: Progressive models (groups increase in maturity and performance over time), cyclical models (terminal phase of model begins the process again), and nonsequential models (de-emphasizes linearity). The authors found these models to have much in common, including the stages of group development and process, allowing for reliable theory and design heuristics while researchers continue to develop more dynamic models representing the influence of the larger system.

In discussing online learning groups specifically, Carabajal et al. (2007) outlined three key elements: Technology, people, and tasks. While desiring not to focus exclusively on technology, Carabjal et al. pointed out that "ICT-rich" environments (Baskin, Barker, and Woods 2005) could enable new group processes without restrictions in medium (they are not text only), timing, and response lag. More recent technologies have allowed research to progress beyond asynchronous discussion board interactions. Carabajal et al. explained that these emerging technologies have technical and social components. The technical dimension supports how the learning is managed, how documents are organized and transferred, and how instructors and students monitor learning progress. The social dimension is created as the technologies support social cues about interactions, norms, and the "presence” of other members (Blanchard 2004).

Carabajal and colleagues (2007) reported OLGs are often more on-task, especially when role assignment is clarified early (Guadagno and Cialdini 2002), and they can be more effective at producing ideas (Valacich, Dennis, and Connolly 1994). Carabajal et al. reason that this could be why OLGs have more difficulty 
reaching consensus. Information overload also becomes a problem, and these authors marked this as a characteristic of group size and social behavior, with around 25 members being ideal for classes/communities and three to five members ideal for small group work (Fisher, Thompson, and Silverberg 2004/2005). Still, there is much room for improved on-task behavior in online learning, as some researchers have reported that $42 \%$ of group online messages can be relationship rather than task-oriented (Palloff and Pratt 1999), and that groups can trend towards cooperation on a task rather than collaboration in learning (Paulus 2005).

The social nature of online learning groups is important as "it is social behavior that sustains the online group over time" (Carabajal et al. 2007, p. 144) and "without group-maintenance activities, even the wide assortment of synchronous and asynchronous technologies cannot sustain the . . group (p. 145). Because of this, the authors cautioned that the tendency of online groups to be more on task can negatively impact the group's social nature, hindering group decision making. However, researchers have found that online groups can be taught to establish norms to strengthen the group (Graham 2003) and can have even stronger social ties than face-to-face groups (Walther 1996).

\section{Supporting learner subgroups}

The section of the Handbook on learners and learning also contained chapters related to the effective support of specific subgroups of learners. These chapters bring the findings related to the successes and challenges of distance learning down to the level of individual student needs.

\section{Supporting K-12 Learners}

Supplemental online education for as much as $1 / 3$ rd of $\mathrm{K}-12$ schools is rapidly doubling every two years (Watson, Gemin, and Ryan 2008), and full-time online education is also growing, making this an increasingly important distance learning population. This presents challenges, as Cavanaugh (2007) explained, because distance learning requires autonomy and an internal locus of control, which K-12 students often lack. Still, Cavanaugh found agreement in five research metaanalyses (total number of research studies=367) that K-12 students appeared to learn as well or slightly better online as in face-to-face environments (Cavanaugh 2001; Shachar and Neumann 2003; Bernard, et al. 2004; and Cavanaugh, Gillan, Kromrey, Hess, and Blomeyer 2004). However, many of these studies showed a small effect size or the difference fell within the confidence interval, indicating no statistical significance. Still, Cavanaugh (2007) concluded that when the online instruction is designed well, K-12 students appeared to have an equal chance for success as they would in a face-to-face class. 
Cavanaugh (2007) also found that K-12 success online depended on applying strong academic and technical skills, motivation, and discipline (Roblyer and Marshall 2003; Weiner 2003). For example, the Educational Success Prediction Instrument (ESPRI) is one instrument that has been used to accurately discriminate between successful and unsuccessful online students (between 95 and 100 percent accuracy) based on skills and learning styles such as the students' computer confidence, achievement beliefs, responsibility, self-organization, technology skill/access, study environment, and even their out-of-school activities (Ferdig, DiPietro, and Papanastasiou 2005; Roblyer and Marshall 2003).

In addition, online courses must be effectively designed internally as well as institutionally to maximize student achievement. For example, she cited Weiner's (2003) study as indicating that effective online courses were more structured with clear expectations, deadlines, and study guides, and allowed for student collaboration, although flexibility so students can self-regulate their learning is also important. Other authors have discussed methods for designing institutional support of K-12 online learning, but research evidence is still needed to determine the effect of these methods on achievement.

As Cavanaugh (2007) found, the biggest challenge facing K-12 online learning is a lack of research compared to what has been done for adult learners. There are still many unanswered questions about how online learning is different—or could be different-for K-12 online learners when compared with adult online learners or K12 face-to-face students.

\section{Supporting Female Students}

Online courses often have more women than men (Sikora 2002), but these students have many unique challenges that Kramarae (2007) described in her chapter of the Handbook. For example, women might not find the courses offered online that are needed for the degrees that are interesting to them (Kramarae 2001), and their lived experiences are often less likely to be integrated into the curriculum (Kramarae and Zhang 2002). In addition, online computer-mediated communication is often male-dominated (Herring 2000; 2003; 2004), unless the instructor moderates the discussion (Herring 2000). Another challenge is that women have disproportionately less access to the home computer (Gunn, McSporran, MacLeod, and French 2003). They also must juggle schoolwork with an average of six other major responsibilities (Cragg, Andrusyszyn, and Fraser 2005) including full time work, marriage, and parenting. This can make finding a common time for online group work difficult.

To overcome these challenges, Kramarae (2007) outlines some recommendations, including preparing a supportive and social environment for the learning where students can feel a sense of belonging and know how to contact and receive help from the instructor and other students. She also recommends 
recognizing the diversity within the course and the special needs and strengths of female online learners when considering group work and discussion strategies.

\section{Supporting Distance Learners Through Academic Advising}

Academic advising is always important for student success, but particularly in online learning where, as Curry and Barham (2007) pointed out, the students are usually older, working full time, and interacting with the institution only through their advisor. These authors found little research on academic advising for distance students, and the most comprehensive study (Curry, Baldwin, and Sharpe 1998) was no longer current. In reviewing the few studies available, the authors first cited international studies. In two of these, students reported it was important to have services about specific programs and degrees, general opportunities, course selection advice, technology orientation, application assistance, identifying and managing fears, building academic skills, considering work and financial commitments, and identifying support networks (Bird and Morgan 2003; Potter 1998). Another study found some evidence that advising can be effective through distance technologies, in this case audio teleconferencing (Lalande 1995), while in another study, about two-thirds of the students said the advising they received through teleconferencing was helpful, but not sufficient (Carr and Ledwith 1980).

In citing studies completed in the United States, Curry and Barham (2007) reported that in one study, the most helpful services for students were the admission process, along with Continuing Education staff assistance, followed by contact with advisors and a sense of belonging to the university (Tallman 1994). In Curry's own doctoral dissertation (1997), he conducted a national survey of academic advising in distance education and found that these programs provided better student advising than institutions as a whole (something Brown 2004 also found) and satisfactory relationships between students and advisors through telephone, in-person visits, mail, and Internet communication. These findings indicate that for distance learners, academic advising is particularly important and can be effective.

\section{Supporting Disabled Students}

Kinash and Crichton (2007) only found 17 research studies between 2000 to 2006 on disabled distance learners. Looking more closely at seven of these studies, Kinash and Crichton found some indication that computers have potential for improving accessibility (Fichten, Asuncion, Barile, Fossey, and de Simone 2000; Fichten, Asuncion, Alapin, Barile, Gaulin, Guimont, et al. 2001, 192), and that increasing distance education technologies can lead to better outcomes for disabled students, particularly when technical assistance is provided to improve accessibility (e.g. text transcription), home computers and assistive devices are available, and individualized education/accommodation plans are developed (Kim-Rupnow and 
Burgstahler 2001). Kinash and Crichton (2007) also found that the most common distance technologies used for assisting disabled students are mainstream technologies such as course management systems, spell checkers, and scanners, which can also improve learning for non-disabled students.

\section{Supporting Distance Learners Through Academic Libraries}

As distance learning grows in higher education, information specialists and librarians are adapting. Dew (2007) described research and practices growing rapidly in this area, particularly since the first issues in 2003 of the Journal of Library and Information Services in Distance Learning. In addition, academic librarians have professional resources through the Distance Learning Section of the Association of College and Research Libraries (ACRL), international conferences, and ACRL's Guidelines for Distance Learning Services. These professional services help librarians with their new roles in distance education, including providing library instruction, reference services, electronic reserves, expertise on information literacy and copyright issues, and developing the flexibility to integrate library services into different modes of distance education delivery.

\section{Concluding thoughts}

Despite the advances made in distance learning research, the Handbook authors found many areas where more research is needed. In learner autonomy, Anderson (2007) describes many good questions that are unanswered, including: Do the more socially interactive modes of technology used in distance education impact the extent to which metacognitive strategies are used, what is the extent to which DL students use cognitive/metacognitive strategies and is this different from F2F students, how do cognitive/metacognitive strategies impact DL outcomes, and how can a DL course be designed to foster these metacognitive/cognitive skills and knowledge?

Hannafin et al. (2007) found that while there was much research on extrinsic cognitive load in DL, more is needed concerning the impact of DL on intrinsic and germane load. Carabajal et al. (2007) outlined future research directions about how to effectively develop groups, particularly within common temporal constraints. In addition, they argued for more research into how to evaluate group-based learning products and shift the locus of learning from instructor-driven to group-developed. Allen et al. (2007) indicated a need for more long-term research into student satisfaction, including why students leave DL programs, what student learning needs are best matched to what environments, and whether modern technology can reverse the trend of less student satisfaction with synchronous communication compared with asynchronous. From Cavanaugh's (2007) chapter, it is apparent that 
more research in grades K-8 is needed, as well as knowledge about how to design DL specifically for younger students.

Curry and Barham (2007) explained that the research on academic advising is limited by low response rates and a lack of generalizability, and a need exists for regular replication of a national survey such as Curry's (1997). A lack of current and thorough research still exists as well on disabled DL learners, and library media specialists still have many unanswered questions about what are the most effective, satisfactory, and convenient methods of providing services. These findings indicate that while progress has been made in understanding the impacts of DL in general on learners and learning, there is much still to be learned about the effects on specific subgroup populations.

\section{References}

Allen, J., J. Bourhis, N. Burrell, and E. Mabry. 2002. Comparing student satisfaction with distance education to traditional classrooms in higher education: A meta-analysis. The American Journal of Distance Education 16(2), 83-97.

Allen, M., N. Burrell, and E. Timmerman. 2007. In Handbook of distance education, ed. M. G. Moore, 149-156. Mahwah, NJ: Lawrence Erlbaum Associates, Inc.

Anderson, B. 2007. Independent learning. In Handbook of distance education, ed. M. G. Moore, 109-122. Mahwah, NJ: Lawrence Erlbaum Associates, Inc.

Bannert, M. 2003. Effects of metacognitive help on knowledge acquisition in Web-based learning environments. German Journal of Educational Psychology 17(1), 13-25.

Baskin, C., M. Barker, and P. Woods. 2005. When group work leaves the classroom does group skills development also go out the window? British Journal of Educational Technology 36(1), 19-31.

Bernard, R. M., P. C. Abrami, Y. Lou, E. Borokhovski, A. Wade, L. Wozney, P. A. Wallet, M. Fiset, and B. Huang. 2004. How does distance education compare with classroom instruction? A meta-analysis of the empirical literature. Review of Educational Research 74(3), 379-439.

Bird, J. and C. Morgan. 2003. Adults contemplating university study at a distance: Issues, themes, and concerns. International Review of Research in Open and Distance Learning (4)1.

Blanchard, A. 2004. Virtual behavior settings: An application of behavior setting theories to virtual communities. Journal of Computer Mediated Communication 9(2), 65-79.

Bures, E. M., Amundsen, C. C., and Abrami, P. C. (2002). Motivation to learn via computer conferencing: Exploring how task-specific motivation and CC expectations are related to student acceptance of learning via CC. Journal of Educational Computing Research 27(3), 249-264. 
Carabajal, K., D. LaPointe, and C. N. Gunawardena. (2007). Group development in online distance learning groups. In Handbook of distance education, ed. M. G. Moore, 123-136. Mahwah, NJ: Lawrence Erlbaum Associates, Inc.

Cavanaugh, C. 2001. The effectiveness of interactive distance education technologies in K-12 learning: A meta-analysis. International Journal of Educational Telecommunications 7(1), 73-78.

Cavanaugh, C., K. Gillan, J. Kromrey, M. Hess, and R. Blomeyer. 2004. The effects of distance education on K-12 student outcomes: A meta-analysis. Naperville, IL, Learning Point Associates. http://www.ncrel.org/tech/distance/k12distance.pdf.

Cavanaugh, C. (2007). Student achievement in elementary and high school. In Handbook of distance education, ed. M. G. Moore, 123-136. Mahwah, NJ: Lawrence Erlbaum Associates, Inc.

Chen, Y.-J. and F. K. Willits. 1998. A path analysis of the concepts in Moore's theory of transactional distance in a videoconferencing learning environment. Journal of Distance Education 13(2), 51-65.

Chen, Y.-J., and Willits, F. K. 1999. Dimensions of educational transactions in a videoconferencing learning environment. The American Journal of Distance Education 13(1), 45-59.

Clarke, T., P. Ayres, and J. Sweller. 2005. The impact of sequencing and prior knowledge on learning mathematics through spreadsheet applications. Educational Technology, Research, and Development 53(3), 15-24.

Cragg, C. E., M. Andrusyszyn, and J. Fraser. (2005). Sources of support for women taking professional programs by distance education. Journal of Distance Education 20(1), 2138.

Curry, R. F. 1997. Academic advising in distance education. (Doctoral Dissertation, College of William and Mary, 1997). Dissertation Abstracts International 58-02 A, 396.

Curry, R. F., Baldwin, R. G., and Sharpe, M. S. (1998). Academic advising in baccalaureate distance education programs. The American Journal of Distance Education 12(3), 42-52.

Curry, R. F. and P. D. Barham (2007). Academic advising in degree programs. In Handbook of distance education, ed. M. G. Moore, 123-136. Mahwah, NJ: Lawrence Erlbaum Associates, Inc.

DeTure, M. 2004. Cognitive style and self-efficacy: Predicting student success in online distance education. The American Journal of Distance Education 18(1), 21-38.

Dew, S. H. (2007). The role of academic libraries. In Handbook of distance education, ed. M. G. Moore, 123-136. Mahwah, NJ: Lawrence Erlbaum Associates, Inc.

Eveland, W. P., J. Cortese, J., H. Park, and S. Dunwoody, S. 2004. How Web site organization influences free recall, factual knowledge, and knowledge structure density. Human Communication Research 30(2), 208-233.

Fichten, C. S., J. V. Asuncion, M. Barile, M. Fossey, and C. de Simone. 2000. Access to educational and instructional computer technologies for post-secondary students with 
disabilities: Lessons from three empirical studies. Journal of Educational Media 25(3): 179-201.

Fichten, C. S., J. V. Asuncion, M. Barile, C. Généreux, M. Fossey, D. Judd, et al. (2001). Technology integration for students with disabilities: Empirically based recommendations for faculty. Educational Research and Evaluation 7(2-3): 185-221.

Fisher, M., G. S. Thompson, and D. A. Silverberg. 2004/2005. Effective group dynamics in e-learning: Case study. Journal of Educational Technology Systems 33(3), 205-222.

Garrison, D. R. 1997. Self-directed learning: Toward a comprehensive model. Adult Education Quarterly 48(1), 18-33.

Graham, C. R. 2003. A model of norm development for computer-mediated teamwork. Small Group Research 34(3), 322-352.

Guadagno, R. E. and R. B. Cialdini. 2002. Online persuasion: An examination of gender differences in computer-mediated interpersonal influence. Group Dynamics: Theory, Research, and Practice 1(6), 38-51.

Gunn, C., M. McSporran, H. Macleod, and S. French. (2003). Dominant or different? Gender issues in computer supported learning. Journal of Asynchronous Learning Networks 7(1). Retrieved May 18, $2009 \quad$ at http://www.sloanc.org/publications/jaln/v7n1/pdf/v7n1_gunn.pdf.

Hannafin, M. J., J. R. Hill, L. Song, and R. E. West. 2007. Cognitive perspectives on technology-enhanced distance learning environments. In Handbook of distance education, ed. M. G. Moore, 123-136. Mahwah, NJ: Lawrence Erlbaum Associates, Inc.

Hee Jun, C. and S. D. Johnson. 2005. The effect of context-based video instruction on learning and motivation in online courses. American Journal of Distance Education 19(4), 215-227.

Herring, S. C. 2003. Gender and power in online communication. In J. Holmes and M. Meyerhoff (Eds.), The handbook of language and gender (pp. 202-228). Oxford: Blackwell.

Hsinyi, P., T. Chin-Chung, and W. Ying-Tien. 2006. University students' self-efficacy and their attitudes toward the Internet: The role of students' perceptions of the Internet. Educational Studies 32(1), 73-86.

Jegede, O., M. Taplin, R. Y. K. Fan, M. S. C. Chan and J. Yum. 1999. Differences between low and high achieving distance learners in locus of control and metacognition. Distance Education 20(2), 255-273.

Kaufman, D. F. 2004. Self-regulated learning in Web-based environments: Instructional tools designed to facilitate cognitive strategy use, metacognitive processing, and motivational beliefs. Journal of Educational Computing Research 30(1 \& 2), 139-161.

Kim-Rupnow, W. S., P. W. Dowrick and L. S. Burke. 2001. Implications for improving access and outcomes for individuals with disabilities in postsecondary distance education. The American Journal of Distance Education 15(1), 25-40.

Kinash, S. and S. Crichton. (2007). Supporting the disabled student. In Handbook of distance education, ed. M. G. Moore, 123-136. Mahwah, NJ: Lawrence Erlbaum Associates, Inc. 
Kramarae, C. and W. Zhang. 2002. At home in education: The future of online learning for women. In C. Floyd, G. Kelkar, S. Klein-Franke, C. Kramarae, and C. Limpangog (Eds.), Feminist challenges in the Information Age (pp. 241-251). Opladen, Germany: Leske + Budrich.

Kramarae, C. (2007). Gender matters in online learning. In Handbook of distance education, ed. M. G. Moore, 123-136. Mahwah, NJ: Lawrence Erlbaum Associates, Inc.

LaLande, V. 1995. Student support via audio teleconferencing: Psycho-educational workshops for post-bachelor nursing students. The American Journal of Distance Education 9(3), 62-73.

Land, S. M. and B. A. Greene 2000. Project-based learning with the World Wide Web: A qualitative study of resource integration. Educational Technology, Research, and Development 44(3), 37-53.

Moore, M. G. 1980. Independent study. In R. Boyd \& J. Apps (Eds.), Redefining the discipline of adult education (pp. 16-31). San Francisco: Jossey-Bass.

Moore, M. G., ed. 1997. Handbook of distance education. Mahwah, NJ: Lawrence Erlbaum Associates, Inc.

Niederhauser, D. S., R. E. Reynolds, D. J. Salmen, and P. Skolmoski. 2000. The influence of cognitive load on learning from hypertext. Journal of Educational Computing Research, 18(3), 217-230.

Paulus, T. M. 2005. Collaborative and cooperative approaches to online group work: The impact of task type. Distance Education 26(1), 111-125.

Peters, O. 1998. Learning and teaching in distance education. London: Kogan Page.

Potter, J. 1998. Beyond access: Student perspectives on support service needs in distance learning. Canadian Journal of University Continuing Education 24(1), 59-82.

Roblyer, M. and J. Marshall. (2003). Predicting success of virtual high school students: Preliminary results from an educational success prediction instrument. Journal of Research on Technology in Education 35(2), 241-255.

Schmeeckle, J. M. (2003). Online training: An evaluation of the effectiveness and efficiency of training law enforcement personnel over the Internet. Journal of Science Education and Technology 12(3), 205-260.

Schrum, L., Burbank, M. D., Engle, J., Chambers, J. A., and Glassett, K. F. 2005. Postsecondary educators' professional development: Investigation of an online approach to enhancing teaching and learning. Internet and Higher Education 8(4), 279-289.

Shachar, M. and Y. Neumann. 2003. Differences between traditional and distance education academic performances: A meta-analytic approach. International Review of Research in Open and Distance Learning. Retrieved June 3, 2009, from http://www.irrodl.org/index.php/irrodl/issue/view/16.

Sikora, A. C. (2002. A profile of participation in distance education: 1999-2000. Education Statistics Quarterly 4(4). Retrieved December 20, 2006 from http://nces.ed.gov/programs/quarterly/vol_4/4_4/q4_3.asp. 
Smidt, E., and V. Hegelheimer. 2004. Effects of online academic lectures on ESL listening comprehension, incidental vocabulary acquisition, and strategy use. Computer Assisted Language Learning 17(5), 517-556.

Tallman, F. D. 1994. Satisfaction and completion in correspondence study: The influence of instructional and student-support services. The American Journal of Distance Education $8(2), 43-57$.

Valacich, J. S., A. R. Dennis, and T. Connolly. 1994. Idea generation in computer-based groups: A new ending to an old story. Organizational Behavior and Human Decision Processes 57, 448-467.

Walther, J. B. 1996. Computer-mediated communication: Impersonal, interpersonal and hyperpersonal interaction. Communication Research 23(1), 3-43.

Watson, J., B. Gemin, and J. Ryan. 2005. Keeping pace with K-12 online learning: A review of state-level policy and practice. Retrieved June 5, 2009, from http://www.kpk12.com/downloads/KeepingPace_2008.pdf

Weiner, C. 2003, July-September. Key ingredients to online learning: Adolescent students study in cyberspace. International Journal on E-learning 2(3): 44-50.

Whipp, J. L. and S. Chiarelli. 2004. Self-regulation in a Web-based course: A case study. Educational Technology, Research, and Development 52(4), 5-22.

White, C. 1995. Autonomy and strategy use in distance foreign language learning: Research findings. System 23(2), 207-221.

White, C. 1997. Effects of mode of study on foreign language learning. Distance Education 18(1), 178-196.

White, C. 1999. The metacognitive knowledge of distance learners. Open Learning 13(3), 3746.

Zion, M., T. Michalsky, and Z. Mevarech. 2005. The effects of metacognitive instruction embedded within an asynchronous learning network on scientific inquiry skills. International Journal of Science Education 27(8), 957-983. 